\title{
Analisa Geokimia Fluida Manifestasi Permukaan di Daerah Panas Bumi Lahendong
}

\author{
Jeferson Polii*, Alfrie M. Rampengan
}

Jurusan Fisika FMIPA Universitas Negeri Manado, Tondano, 95619, Indonesia

\begin{tabular}{l} 
I N F O A R T I K E L \\
\hline Diterima 19 April 2020 \\
Disetujui 29 April 2020 \\
\\
\hline Key word: \\
Geothermal \\
Lahendong \\
Geochemical \\
\\
\hline Kata kunci: \\
Panas Bumi \\
Lahendong \\
Geokimia
\end{tabular}

*e-mail:

jefersonpolii@unima.ac.id

*Telp: 08524000439

\begin{abstract}
A B STRACT
Geothermal energy depends on volcanic regions or plate subduction. Indonesia has geothermal potential due to the meeting of 3 (three) large plates. North Sulawesi is one of the areas located in the ring of fire. Some areas in the Minahasa Regency, North Sulawesi province, were targeted for research because they have manifestations of geothermal such as hot pools, steaming ground, mud pools, and other manifestations. The research location is divided into 3 (three) locations around the Lahendong geothermal area, namely the Lahendong pine forest, the Toraget hot air area, and the hot springs in the village of Totolan. The results of sample and ploting tests in ternary diagrams show that all three geothermal manifestations have sulfuric acid type fluids. This type of geothermal fluid has a high SO4 content, while $\mathrm{HCO} 3$ and $\mathrm{Cl}$ values are low. Hot springs that have a type of sulfuric acid occur in active volcanic regions. This is supported by the lithology of three areas of manifestation which are composed of basalt resulting from volcanic rocks.
\end{abstract}

\begin{abstract}
ABSTRAK
Energi panas bumi cenderung berada di daerah vulkanik maupun subduksi lempeng. Indonesia memiliki potensi panas bumi karena berada di pertemuan 3 (tiga) lempeng besar. Sulawesi Utara menjadi salah satu daerah yang terletak di pada jalur cincin api. Beberapa daerah di Kabupaten Minahasa, propinsi Sulawesi Utara, menjadi sasaran penelitian karena memiliki manifestasi panas bumi seperti mata air panas, tanah beruap, lumpur panas, dan manifestasi lainnya. Lokasi penelitian dibagi menjadi 3 (tiga) lokasi di seputaran daerah panas bumi Lahendong, yaitu hutan pinus Lahendong, daerah air panas Toraget, dan mata air panas di desa Totolan. Hasil uji sampel dan ploting pada diagram ternary menunjukkan bahwa ketiga manifestasi panas bumi memiliki fluida tipe asam sulfat. Fluida panas bumi jenis ini memiliki kandungan $\mathrm{SO}_{4}$ tinggi, sedangkan nilai $\mathrm{HCO}_{3}$ dan $\mathrm{Cl}$ rendah. Mata air panas yang memiliki jenis asam sulfat cenderung terjadi pada daerah vulkanik aktif. Hal ini didukung dengan kondisi litologi ketiga daerah manifestasi yang tersusun oleh batuan basalt berumur tersier hasil dari batuan vulkanik.
\end{abstract}

\section{Pendahuluan}

Panas bumi merupakan salah satu energi terbarukan (renewable energy) karena sumber panasnya yang berasal dari uap panas bertekanan tinggi yang berasal dari lapisan kerak bumi bawah permukaan yang sumber panasnya dari magma. Jika aliran siklus fluida permukaan yang masuk ke reservoir panas bumi. Jika uap panas ini dipertahankan debitnya maka aliran panas bumi ke permukaan akan berkelanjutan (sustainable). Energi panas bumi juga menjadi energi yang unggul karena emisi $\mathrm{CO}_{2}$ dan gas tak terkondensasi lainnya cukup kecil sehingga energi panas bumi menjadi ramah lingkungan. 
Indonesia memiliki potensi panas bumi $40 \%$ dari keseluruhan potensi dunia atau sekitar 30.000 MW. Namun kapasitas terpasang baru mencapai 1.450 MW [1]. Hal ini mengindikasikan bahwa panas bumi di Indonesia masih perlu dikembangkan tahap eksplorasi maupun eksploitasinya. Energi panas bumi cenderung berada di daerah vulkanik maupun subduksi lempeng. Indonesia memiliki potensi panas bumi karena berada di pertemuan 3 (tiga) lempeng besar. Sulawesi Utara menjadi salah satu daerah yang terletak di pada jalur cincin api. Pengembangan panas bumi pun di Sulawesi Utara sudah cukup memadai.

Sebagian besar daerah panas bumi Indonesia memiliki sistem hidrotermal bertemperatur tinggi (di atas $225^{\circ} \mathrm{C}$ ). Sistem hidrotermal dapat didefinisikan sebagai sistem perpindahan panas bumi dari sumber panas ke permukaan dengan konveksi bebas, dengan melibatkan fluida meteorik disertai atau tanpa fluida magmatic [2]. Sistem panas bumi hidrotermal dapat ditunjukkan dengan gambar 1.

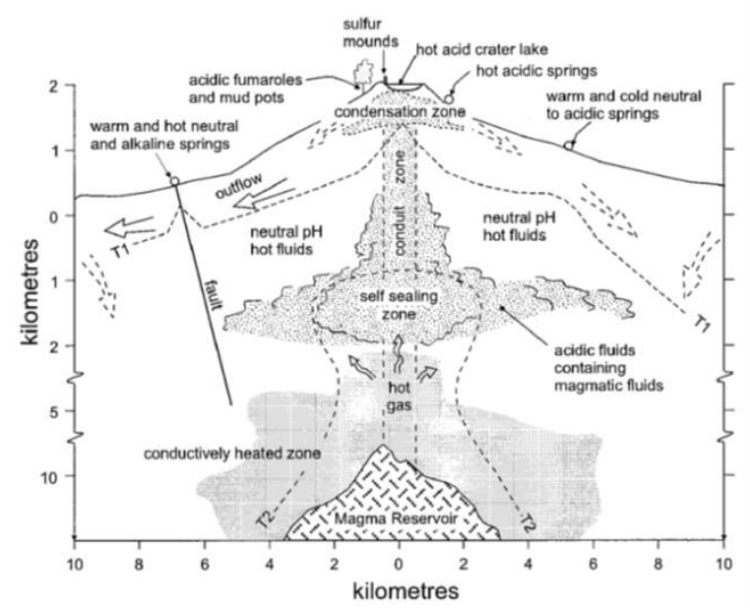

Gambar 1. Sistem Panas Bumi Hidrotermal [3].

Model sistem panas bumi hidrotermal menjadi prospek jangka panjang jika didukung oleh 5 (lima) aspek penting berikut.

- Sumber panas bumi yang besar

- Reservoir yang permeabel

- Adanya aliran air

- Lapisan penudung (cap rock)

- Mekanisme peresapan
Kelima aspek tersebut saling membangun dan membentuk sistem panas bumi hidrotermal yang dapat dieksploitasi. Kurangnya salah satu aspek akan membuat lapangan pada sistem panas bumi ini tidak dapat dieksploitasi [3].

Kenampakan manifestasi di permukaan dapat mengindikasikan adanya potensi panas bumi di daerah tersebut. Manifestasi panas bumi dapat berupa mata air panas, fumarol, tanah beruap, kolam lumpur panas, dan manifestasi lainnya. Kolam air panas terbentuk karena ada rembesan air panas dari bawah permukaan melalui rekahan-rekahan pada batuan. Kenaikan temperatur pada fluida ini bisa disebabkan karena fluida tersebut berasal dari reservoir, atau pun berasal dari air permukaan yang menjadi panas karena kontak dengan uap panas. Air panas yang bersumber dari reservoir cenderung berwarna jernih kebiru-biruan. Untuk air panas yang berasal dari tanah yang kontak dengan uap panas memiliki $\mathrm{pH}$ rendah dan berwarna kehijauhijauan [4].

\section{Metode}

Penelitian dilakukan di 3 (tiga) daerah manifestasi panas bumi yaitu di hutan pinus Lahendong, pemandian air panas Toraget di Langowan, dan daerah air panas berlumpur di desa Totolan di Kakas. Sampel air dari tiga tempat itu di ambil dan dianalisis menggunakan spektrofotometer UV-Vis. Manifestasi di ketiga daerah tersebut yang nampak seperti mata air panas, uap panas, tanah beruap, dan lumpur panas.

\section{Hasil dan Pembahasan}

Analisa Geokimia Fluida Manifestasi Panas Bumi

Dari hasil sampling air panas di lapangan panas bumi setelah di analisa di labolatorium dapat dilakukan karakterisasi jenis fluida lapangan. dengan melakukan ploting hasil analisa laboratorium pada diagram ternary. Dan ini contoh diagram ternary $\mathrm{Cl}-\mathrm{SO}_{4}-\mathrm{HCO}_{3} \mathrm{di}$ tunjukan pada gambar 2 berikut : 


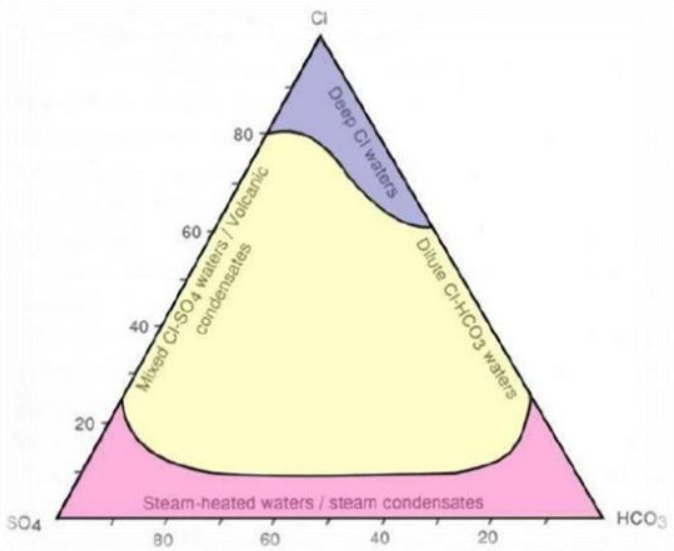

Gambar 2. Diagram Ternary [5]

Diagram Ternary Plot berfungsi untuk mengklasifikasi air panas bumi berdasarkan kandungan sulfat, klorida, dan bikarbonat [5].

Air klorida dicirikan dengan kandungan $\mathrm{Cl}$ yang tinggi, mengandung sejumlah $\mathrm{HCO}_{3}$, dan perbandingan $\mathrm{Cl} / \mathrm{SO}_{4}$ yang tinggi. Air klorida mengandung $\mathrm{Na}, \mathrm{K}$ tinggi, dan $\mathrm{SiO}_{2}$ tinggi. Air ini memiliki $\mathrm{pH}$ netral dan kenampakan manifestasi air panasnya jernih dan berwarna kebiru-biruan. Air klorida yang bertemperatur tinggi akan memiliki endapan silika di sekitarnya.

Air asam sulfat memiliki kandungan $\mathrm{SO}_{4}$ yang tinggi, dan umumnya memiliki kandungan $\mathrm{Cl}$ dan $\mathrm{HCO}_{3}$ yang rendah. Air asam sulfat memiliki derajat keasaman yang rendah (nilainya berkisar 2-3). Fluida ini berasal dari kondensasi uap dari bawah permukaan seperti yang terjadi di daerah vulkanik.

Air bikarbonat memiliki kandungan $\mathrm{HCO}_{3}$ yang tinggi dengan nilai $\mathrm{Cl}$ dan $\mathrm{SO}_{4}$ yang bervariasi. Air bikarbonat memiliki $\mathrm{pH}$ netral, tetapi bila terlarut $\mathrm{CO}_{2}$ di permukaan maka fluidanya akan menjadi basa. Pada daerah manifestasi yang mengandung air bikarbonat sering terdapat endapan travertin di sekitarnya.

\section{Pengujian Sampel Fluida Manifestasi Panas Bumi}

Penelitian dilakukan di 3 (tiga) daerah manifestasi panas bumi yaitu di hutan pinus Lahendong, pemandian air panas Toraget di Langowan, dan daerah air panas berlumpur di desa Totolan di Kakas.

Sampel air yang diperoleh di ketiga daerah manifestasi kemudian diuji dengan menggunakan spektrofotometer UV-Vis. Hasil pengujian sampel pada ketiga daerah tersebut ditunjukan dengan tabel 1 berikut.

Tabel 1. Koordinat dan Komposisi Kimia Fluida Manifestasi

\begin{tabular}{|c|c|c|c|}
\hline \multirow{2}{*}{$\begin{array}{c}\text { Daerah } \\
\text { Manifestasi }\end{array}$} & \multicolumn{3}{|c|}{$\begin{array}{c}\text { Komposisi Kimia Air } \\
(\mathrm{mg} / \mathrm{L})\end{array}$} \\
\hline & $\mathrm{Cl}$ & $\mathrm{SO}_{4}$ & $\mathrm{HCO}_{3}$ \\
\hline $\begin{array}{l}\text { Air panas di } \\
\text { hutan pinus } \\
\text { Lahendong }\end{array}$ & 0,49 & 229 & 0,99 \\
\hline $\begin{array}{l}\text { Air panas } \\
\text { Toraget }\end{array}$ & 119 & 442 & 0,99 \\
\hline $\begin{array}{l}\text { Air panas di } \\
\text { desa Totolan }\end{array}$ & 5,3 & 511 & 1 \\
\hline
\end{tabular}

\section{Analisa Fluida Manifestasi}

Penentuan tipe fluida dari ketiga mata air panas manifestasi dengan cara menganalisa secara geokimia menggunakan diagram ternary $\mathrm{Cl}-\mathrm{SO}_{4}-\mathrm{HCO}_{3}$. Analisa berdasarkan data kandungan $\mathrm{Cl}, \mathrm{SO}_{4}$, dan $\mathrm{HCO}_{3}$ yang diperoleh di lokasi penelitian.

Berdasarkan nilai presentase kandungan komposisi kimia masing-masing, selanjutnya dilakukan ploting pada diagram ternary untuk masing-masing daerah manifestasi. Hasil ploting untuk ketiga daerah manifestasi ditunjukkan dengan gambar 3 di bawah ini.

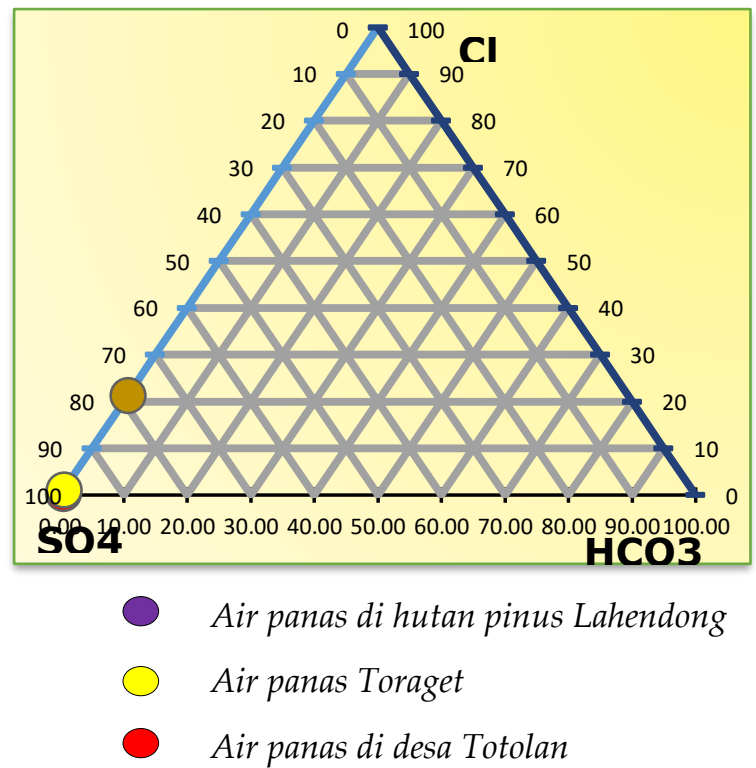

Gambar 3. Ploting Diagram Ternary Fluida Manifestasi Panas Bumi 
Dari diagram di atas dapat dilihat bahwa ketiga manifestasi panas bumi memiliki fluida jenis air asam sulfat. Fluida panas bumi jenis ini memiliki kandungan $\mathrm{SO}_{4}$ tinggi, sedangkan kandungan $\mathrm{HCO}_{3}$ dan $\mathrm{Cl}$ rendah. Mata air panas bertipe asam sulfat berasal dari fluida hasil kondensasi uap panas. Hal ini disebabkan karena fluida ini melarutkan mineral batuan sepanjang perjalanannya ke permukaan. Mata air panas yang memiliki jenis asam sulfat cenderung terjadi pada daerah vulkanik aktif. Hal ini didukung dengan kondisi litologi ketiga daerah manifestasi yang tersusun oleh batuan basalt berumur tersier hasil dari batuan vulkanik.

\section{Kesimpulan}

Hasil uji sampel dan ploting pada diagram ternary bahwa ketiga manifestasi panas bumi memiliki fluida tipe asam sulfat. Fluida panas bumi jenis ini memiliki kandungan $\mathrm{SO}_{4}$ tinggi, sedangkan kandungan $\mathrm{HCO}_{3}$ dan $\mathrm{Cl}$ rendah. Mata air panas yang memiliki jenis asam sulfat cenderung terjadi pada daerah vulkanik aktif. Hal ini didukung dengan kondisi litologi ketiga daerah manifestasi yang tersusun oleh batuan basalt berumur tersier hasil dari batuan vulkanik.

\section{Daftar Pustaka}

1. Wahjosoedibjo, A. S.; Hasan, M. In Indonesia's geothermal development: where is it going, 43rd workshop on geothermal reservoir engineering. Stanford, California: Stanford University, 2018.

2. Hochstein, M.; Browne, P., Surface manifestations of geothermal systems with volcanic heat sources. Encyclopedia of volcanoes 2000, 835-855.

3. DiPippo, R., Geothermal power plants: principles, applications, case studies and environmental impact. ButterworthHeinemann: 2012.

4. Saptadji, N. M., Teknik Panas Bumi. Bandung, Penerbit ITB 2001.

5. Nicholson, K., Geothermal fluids: chemistry and exploration techniques. Springer Science \& Business Media: 2012. 